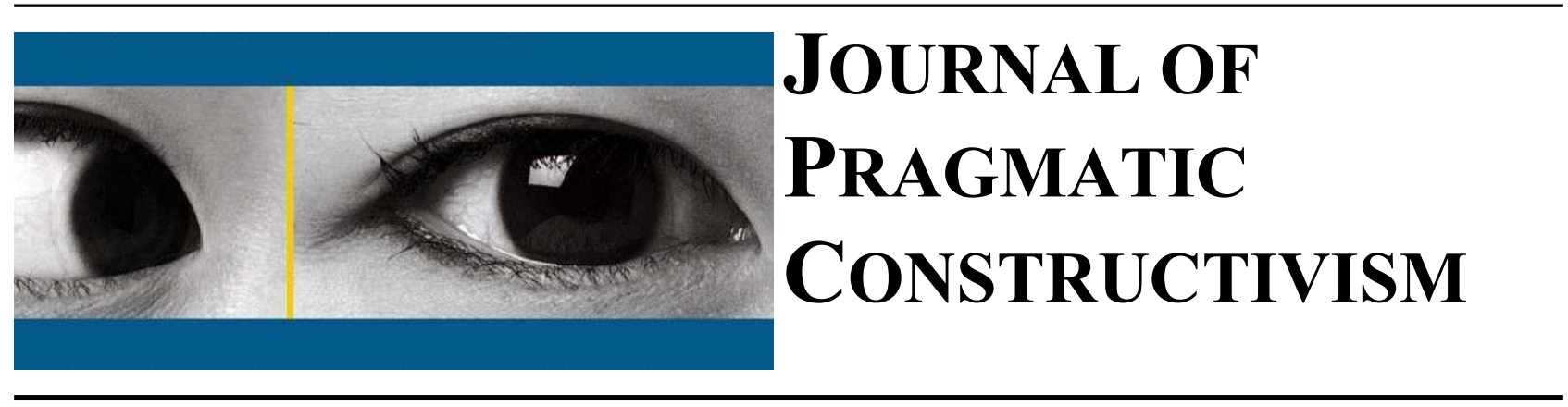

\title{
Language in the technology subject at the Danish Higher Technical Examination Programme - Pragmatic constructivism in practice
}

\author{
Mette Møller Jeppesen \\ Department of Planning, Aalborg University \\ Email:mmj@plan.aau.dk
}

\begin{abstract}
Working with problem-based learning (PBL) in the technology subject differentiates The Higher Technical Examination Programme (HTX) from other secondary school programs in Denmark. Challenges include interpretation of different elements which vary from teacher to teacher as the teachers have very different professional backgrounds. This has consequences for students and indicates that a solid disciplinary tradition has yet to be developed. It could possibly be argued that teachers' communications on the subject, are only abstractions and not concepts. To solve these problems, it seems pertinent to apply the conceptualising method (Nørreklit 1973), to create useful and precise concepts free from possible ambiguities as a contribution to a coordinated language. In conclusion, it has been possible to use Pragmatic Constructivism (PC) to unfold the language games of the technology subject and enable the teachers to discuss their subject with each other thereby creating change in the subject and organisation.
\end{abstract}

Keywords: Danish Higher Technical Examination Programme, Pragmatic constructivism, language game, conceptualising method, organisational change.

\section{Introduction}

In the 1980s the Danish Higher Technical Examination Programme (HTX) was established. The purpose was introducing a high school education stream specifically directed towards science and engineering (Danish Education Ministry, 2015). The first higher technical examination programme was inaugurated as an experiment in 1982; later in 1989 HTX became a permanent addition to high school education in Denmark (Jans, 2007; Olsson, 2007). The study programme was very much influenced by the problem-based learning (PBL) principles of the new Danish universities at Aalborg and Roskilde (Jans, 2007:12); therefore, based upon problem-based learning (PBL) principles which are inherently interdisciplinary with group project work and a high level of student self-direction or student centeredness (Henriksen, 2016a). Problem-oriented project work, especially in the profile subjects Technology and Technical Science, has been a defining HTX characteristic since its inception (Ulriksen et al., 2008; Jans 2007:18; Ministerial order, 2015; Ministry of Children and Education , 2017) and is what differentiates HTX from other second level programmes in the Danish educational system these include STX and HHX ('STX' (General matriculation examination) and 'HHX' (Higher Commercial Examination) are acronyms for other second level programs. The differences are explained in the following). Where STX offers a very broad general education with a focus on many different disciplines such as social and natural sciences, HHX offers business and social economics in combination with more classical teaching subjects and foreign languages but none of the other second level educational programs work problem-oriented as done on HTX. HTX is a three-year educational programme (Ministry of Education, 2008) and is structured as illustrated below in figure 1: 
Field of study $2 \frac{1}{2}$ years Compulsory subjects and levels Three specialisation subjects Multidisciplinary teaching courses Electives Specialised study project

\section{Field of study $21 / 2$ years} Compulsory subjects and levels Three specialisation subjects Multidisciplinary teaching courses Electives

Specialised study project
Field of study $2 \frac{1}{2}$ years Compulsory subjects and levels Three specialisation subjects Multidisciplinary teaching courses Electives

Specialised study project

Basic course $1 / 2$ year

Compulsory subjects and levels: Danish, English, Mathematics

Multidisciplinary teaching courses, including workshop teaching

In figure 1 it is illustrated that the subjects the students follow during their three years of study and they are placed within a system consisting of three level; C, B and A level. Focusing on levels a subject at level C consists of 75 hours of 60 minutes, at level B this is 200 hours and at level A subject consists of 325 hours (Ministry of Education, 2008:1). As illustrated above the students also have to follow compulsory subjects and levels and those include; Danish A, Technology A, English A, physics B, chemistry B, mathematics B, technology B, biology B, communication / IT C, social studies $\mathrm{C}$ and technology history $\mathrm{C}$ (Ministry of Education, 2008:3). Later in their study the students also have to choose a field of study and in doing so they can choose between different field of study packages that all consists of three subjects. The subjects can be combined in three different ways and the students can therefore, choose; three subjects at A level, two subjects at A level and one at B level or one subject at A level, one at B level and one at B or C level. The schools compose the field of study packages themselves which means that the number of fields of study and the content can vary but no matter the school or the choice of field of study a student that finish HTX has at least 2630 hours of 60 minutes (Ministry of Education, 2008:3).

Doing problem-oriented work on HTX presents as challenge for the teachers as I found in ongoing empirical work on HTX there is no shared consensus on conceptualisations of PBL related to the technology subject or nor is there any shared consensus about which methods to use. This presents some challenges for the students as the way they work with PBL and technology projects varies from teacher to teacher and from class to class. This becomes apparent during the students' third year of study when they have to choose a technical science subject; students arrive from different classes and students in this new class may have developed different perceptions of how to work with projects and in the same way it creates challenges for the students when they go to the exam and the teacher and examiner do not agree on what constitutes a good technology project - a disagreement that can also be expressed in the grading of the projects.

Basically, PBL requires that we take our starting point in working with problems; we wish to know more about the problem with the missing consensus between the teachers in the technology subject. We want to investigate this challenge and in doing so, it is pertinent to know the language of the technology subject as the language is our entrance ticket to getting to explore and obtain information about what is going on in the lifeworld of the technology subject. Wittgenstein (1953) uses the term 'language game' about all the different uses of language which also can be applied for the language in the technology subject. Different social groups use different language games. This is also the case within the same national language.

They have their different language games which allow them to communicate with each other and thereby they also have special terms and expressions which only they know and understand. This is though not only for communication purposes, it also demonstrates that they are a member of this particular group. Learning the language game of the technology subject thus requires me to be a part of the technology subject community, by following their practices (Henriksen, 2018:2).

The purpose of this paper is to unfold the language games used in the technology subject on HTX by applying Pragmatic constructivism (PC) and exemplifying how PC can be applied in practice and thereby adding to the existing research field with a more methodical approach to research in PC.

The paper proceeds as follows: a theoretical framework for creating a coordinated language is presented followed by a method section; the empirical findings are then presented; ending with a conclusion that states that it is possible to 
use PC in practice to unfold the language games in the technology subject and through that create a change in the organisation.

\section{Creating a coordinated language using pragmatic constructivism}

With an interest in getting to know the language game in the technology subject, it is important as a starting point to take a step back and start by focusing on the content of the language used in the technology subject. 'Content is necessary - word in themselves are worth nothing' (Henriksen et al., 2004:22).

\subsection{Concepts and the conceptualising method}

For the language in the technology subject to work it has to express facts, logic, values, and communication which are all aspects of reality, to function. The distinction between abstracts and concepts is central here as abstracts can only describe parts of reality while concepts can describe reality as a whole (Henriksen et al., 2004:23).

Figure 2: The difference between abstractions and concepts is illustrated.

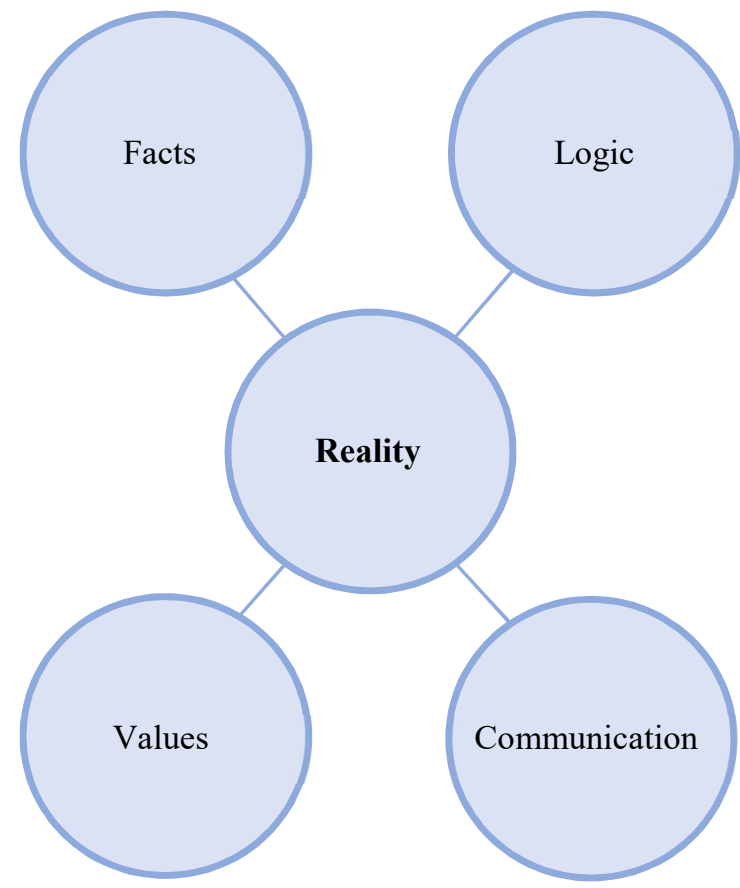

Abstraction

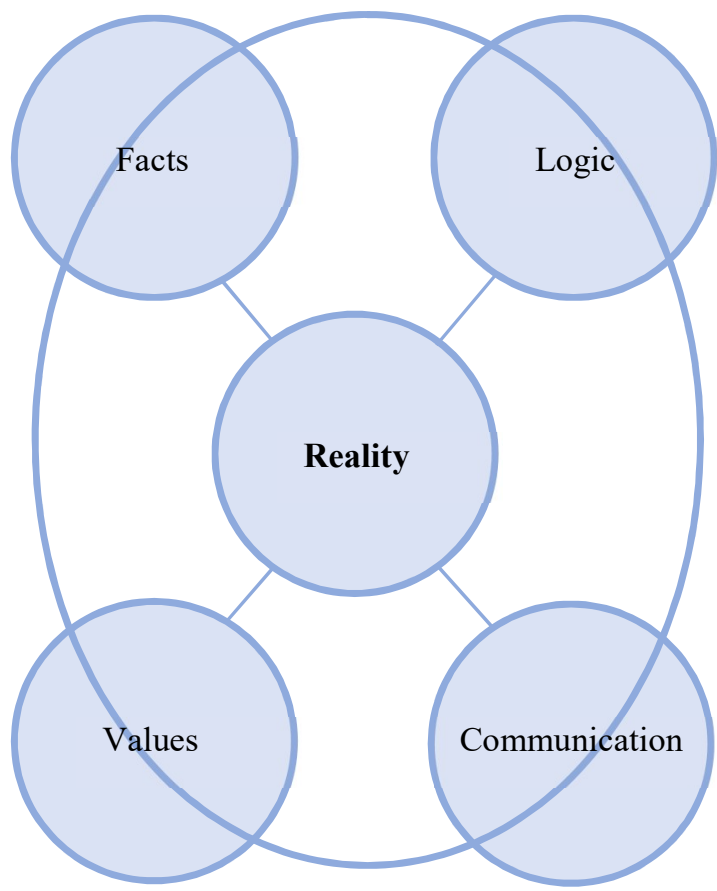

Concept

In order to become familiar with the concepts used in the technology subject, I have to step into their lifeworld as concepts do not just exist but are something that is handed down to us. This happens in a process of conceptualization as when we are given concepts we change them and create new ones (Henriksen et al., 2004:23). In terms of creating useful concepts it is helpful to draw on Nørreklit's (1978) seminal 'conceptualising method'. This method is about taking ordinary words from everyday conversations and changing them into social scientific concepts. Nørreklit (1973) describes concepts as something we possess and can act on: 'Concepts in this sense, are vital to our language games, to our ability to act and change things, and to our ways of understanding the world and our realities' (Henriksen 2016b:30). Preferably, concepts should be precise descriptions of realities, free from possible misinterpretations and ambiguities. In everyday conversations we use concepts and they are often ambiguous and, therefore, often the reason for misunderstandings to such an extent that such concepts are used indifferently in different language games. 
The purpose, in a social scientific investigation, is to remove as many ambiguities as possible which is a real challenge; but this should not prevent us from trying and through our research and using the conceptualisation method create knowledge and concepts (Henriksen, 2016b: 31).

\subsection{Reality, concepts and language games}

'Any encounter into a field of interest is to enter into a lifeworld' (Henriksen, 2018:2). Language is our entrance ticket to getting to explore and obtain information about what is going on in such lifeworlds - in this case the technology subject on HTX. Wittgenstein uses the term 'language game' about all the different uses of language. Different social groups use different language games, even within the same national language. Different groups have their different language games which allow them to communicate with each other and thereby they also have special terms and expressions which only they know and understand. This is not only for communication purposes but in a sense also to demonstrate that they are a member of this particular group. In the case of the technology subject the teachers do not have one language game which is representative of the whole subject and are thereby not able to communicate - they talk past each other.

Learning the language game of the technology subject requires me to be a part of the HTX community, by following their practices. To learn a language does not require us to follow a set of rules, to be understood as we don't first learn grammar when learning a language, and then speaking it. No, we learn it by using it (Henriksen, 2018:2). This is not to say that there are no rules (Henriksen, 2018:2; Lyotard, 1979:9). There are rules, and we need to know how to use the rules of a specific language game in order to participate in a language game; we are just not necessarily able to account for the rules (Henriksen, 2018:2-3). Language is an integrated part of our lifeworlds; it enables us to do a lot of things like asking questions, telling stories and communicating with our fellow human beings. The way to learn about the lifeworlds is, therefore, to learn the language games which constitute, or are constituted by, the specific lifeworld (Henriksen, 2018:3). Language games can change - it rarely remains the same as lifeworlds constantly develop and change. 'Language games change as lifeworlds change and lifeworlds change as language games change' (Henriksen, 2018:3). Such changes happen in the interactions between members of the lifeworld and are often unnoticed. In some cases, language games and lifeworlds diverge which either leaves the members of the community confused and bewildered or in need of changing their language game to fit the new conditions and it may even be necessary to change the lifeworld in some way which is most likely what happened on HTX in the technology field. The language game and the world of life differ, which has led the teachers to come up with their own solutions in the teaching and slowly they have agreed to disagree (Jeppesen, 2020). What Nørreklit (1978) calls a real problem becomes visible here; a real problem is defined as confronting the actors when their language can no longer guide their actions in the lifeworld (Henriksen, 2018:3). As a researcher I should be able to assist in solving real problems if I take part in the process of developing the language game. If I can do so, then I am also able to create a plausible account of the process and turn the process into a social scientific endeavour (Henriksen, 2018:4).

\subsection{Dialog}

As noted above, to be able to assist in solving real problems we need dialog (Henriksen, 2018:4) as access to the reality on HTX is possible through language and communication. Gaining that access is then the next problem I face. Conversations with and between me and the technology teachers therefore seems to be the way to move forward. Conversation here must be understood broadly and can be; small talk, interviews, argument and dialog with the technology teachers which are all important components but in the following a short description of dialog will be made as it is through dialog we become able to create concepts which is needed to develop the language game in the technology subject (Henriksen et al., 2004:152). Dialog in relation to the conceptualizing method can be described as a conversation that is carried out on the logic of question and answer. "The true question is characterized by its authentic nature and its openness. Openness must help to reveal the inner logic of the subject matter, in this case the technology teachers on HTX, and this is only possible if me and the participating teachers involved in the dialog actually use the openness to actively search for the logic of the individual technology teacher. This also means that inauthentic questions which are about showing who is right or rhetorical issues therefore are not involved in the understanding of dialog (Henriksen et al., 2004:158).

\section{Method}

The present article is based on empirical data collected on HTX. The empirical data consists of both observations conducted in the classrooms and interviews with teachers. Over a period corresponding to a full academic year, the observations were carried out on HTX in Aalborg, Denmark. The observations were conducted in twelve different 
classes while during that period of time also discussing the findings with the technology teachers. First-year -, secondyear and third-year students were observed. In selecting the classes in which I was going to observe I took as my starting point some of the introductory meetings I had with the technology teachers. Subsequently, the strategy became applying the snowball effect. It had the practical significance that the technology teachers who from the start had chosen to be participants in the project started talking to other teachers about their participation while I was still in the process of completing the observations and little by little more teachers started to report that they also would like to open up their classrooms and participate.

Observing the teachers in such a series of observations was truly interesting and provided me the access to the lifeworld of the technology subject and allowed me to get to know the language games. Below in table 1 is an overview of the observations:

Table 1: Overview of observations.

\begin{tabular}{|c|c|c|}
\hline Year & Field of study & Department \\
\hline 1st. year students & GAMETECH & $\begin{array}{c}\text { C. A Olesens Gade } \\
\text { Nyhavnsgade 14 }\end{array}$ \\
\hline 1st. year students & International & C. Olesens Gade \\
\hline 1st. year students & Chemistry & Øster Uttrup Vej \\
\hline 1st. year students & Industrial design & Øster Uttrup Vej \\
\hline 1st. year students & Product development & Øster Uttrup Vej \\
\hline 2nd. year students & The world of physics & C. A Olesens Gade \\
\hline 2nd. year students & The world of physics & Øster Uttrup Vej \\
\hline 2nd. year students & GAMETECH/ 1. del & Øster Uttrup Vej \\
\hline 2nd. year students & GAMETECH/ 2. del & Øster Uttrup Vej \\
\hline 3rd. year students & Technology A & Øster Uttrup Vej \\
\hline 3rd. year students & Technology A & Øster Uttrup Vej \\
\hline 3rd. year students & Technical science (B\&E) & Øster Uttrup Vej \\
\hline 3rd. year students & Technical science (B\&E) & Øster Uttrup Vej \\
\hline 3rd. year students & Technical science (B\&E) & Øster Uttrup Vej \\
\hline
\end{tabular}

Table 1 is divided into three columns; year of study, the field of study and the location of the department that is visited.

In addition, insight into the life world and the language games of the technology teachers was also gained through interviews. Supplementing the extensive observations with qualitative interviews I am able to gain a deeper knowledge and insight into the lifeworld and the language games of the technology subject. Nine different teachers, from six different HTX schools throughout Denmark participated in the interviews.

Below table 2 provides an overview of the conducted interviews. 
Table 2: Overview of interviews.

\begin{tabular}{|c|c|c|c|c|c|}
\hline High school & Interviewees & Subjects taught & Years on HTX & $\begin{array}{c}\text { Previous } \\
\text { experiences/ } \\
\text { education }\end{array}$ & Place \\
\hline HTX 1 & Interviewee 1 & $\begin{array}{c}\text { Design, } \\
\text { Technology \& } \\
\text { Technical Science } \\
\text { (Construction \& } \\
\text { Energy) }\end{array}$ & 15 & Cand. polyt & Staffroom \\
\hline HTX 1 & Interviewee 2 & $\begin{array}{c}\text { Technology, } \\
\text { Communication/It } \\
\text { \& Informatics }\end{array}$ & 25 & Cand. polyt. & Staffroom \\
\hline HTX 1 & Interviewee 3 & $\begin{array}{c}\text { Technology \& } \\
\text { Technical Science } \\
\text { (Construction \& } \\
\text { Energy) }\end{array}$ & 25 & $\begin{array}{l}\text { Construction } \\
\text { engineer }\end{array}$ & Staffroom \\
\hline HTX 1 & Interviewee 4 & $\begin{array}{l}\text { Social studies, } \\
\text { History of ideas } \\
\text { and Technology }\end{array}$ & 17 & Master of Arts & Staffroom \\
\hline HTX 2 & Interviewee 5 & Technology & 7 & MSc in Economics & Meeting room \\
\hline HTX 3 & Interviewee 6 & $\begin{array}{l}\text { Technology \& } \\
\text { Mathematics }\end{array}$ & 5 & $\begin{array}{c}\text { Comes from } \\
\text { business }\end{array}$ & Open area \\
\hline HTX 4 & Interviewee 7 & $\begin{array}{c}\text { Technology \& } \\
\text { Technical Science } \\
\text { (Construction \& } \\
\text { Energy) }\end{array}$ & 21 & $\begin{array}{l}\text { Building } \\
\text { constructor }\end{array}$ & Meeting room \\
\hline HTX 5 & Interviewee 8 & $\begin{array}{c}\text { Biology, } \\
\text { Technology \& } \\
\text { Food and Health }\end{array}$ & $18-20$ & Master in Biology & Meeting room \\
\hline HTX 6 & Interviewee 9 & $\begin{array}{c}\text { Technology \& } \\
\text { Chemistry }\end{array}$ & 3 & $\begin{array}{c}\text { Comes from } \\
\text { business/DVM/me } \\
\text { dical industry }\end{array}$ & Meeting room \\
\hline
\end{tabular}

Table 2 provides information on the teachers that were interviewed and is divided into six columns; High School, interviewees, subjects taught, years on HTX, previous experienceleducation and place of interview.

The 'conceptualising method' (Henriksen et al., 2004:147) has been used to collect the empirical data. The method used in the current study is presented in figure 3. 
Figure 3: Illustration of the conceptualising method used to collect data in the study.

- $\quad$ Symptom of HTX Problem

Action - Reflection- (real) Problem

Reflection - Conceptualisation

Action - Reflection

Reflection - Conceptualisation

- $\quad$ (sustainable) Solution to (original) Problem.

The problem that was set forth by the technology teachers; There is a lack of consensus between the teachers in the technology subject on how to work in the subject which has been the offset of the use of the conceptualising method. The question is now how to move further from being proven that there is no consensus between the teacher on how to work in the technology subject, the identification of the need for a coordinated language and on to being able to act on that need. The method can also be of value here as it is used for creating concepts and through the conceptualising process four elements are integrated; facts, logic, values and communication (figure 2). This is done so that the actors involved can create in this case a merged or common language which can enable teachers to easier discuss how they work in the technology subject.

\section{Findings}

In HTX, teachers in the technology subject appear to have no coordinated language in regards to how to work in the subject; it could possibly be argued that teachers' communications here on the subject, on PBL and on project writing are only abstractions and not concepts. To solve these problems, it seems pertinent to apply the conceptualising method (Nørreklit 1973), as it is sought to create useful and precise concepts free from possible misinterpretations and ambiguities as a contribution to a coordinated language in this area. In HTX I have now obtained some knowledge about the use of everyday words related to the technology subject by observing the language in several different classes (see. Table 1), interviewing teachers and I have entered into dialogs with both teachers and students. In the following I, through the collected empirical data, will show what I found.

The starting point for the work was that the teachers expressed that there is no consensus between the teacher about how they work in the technology subject. The teachers seem to 'Agree to disagree' (Jeppesen, 2020). One of the ways in which this became visible was through the following quote:

\section{“(...) Well you can say there are (...) some discussions which are hard to take. Where we gradually might have just gotten to know each other so well so we also gradually just stopped taking the discussion (...)”}

(Interviewee 8, 2019:12).

The teacher who was interviewed here was very conscious about the fact that some discussion between the technology teachers can be difficult and that in some cases the teachers just stopped discussing. This clearly underlines the lack of consensus between the teachers and a further study of 'Agree to disagree' can be read in Jeppesen (2020). With it, the symptoms of the problem technology teachers on HTX have expressed became very clear.

Having been able to identify the symptoms of the problems I continued to observe in the different technology classes subject to different fields of study. Observing and talking to the technology teachers slowly began to give me an insight into the technology subject and during that time I had many interesting dialogs with the technology teachers about how they each teach the technology subject. Product or project, teacher backgrounds and PBL can be mentioned as examples of topics the dialogs I had with the technology teachers revolved around; these are unfolded below. 


\title{
4.1 Product or process
}

Both during the observations in the classes and during the interviews with the teachers, it was very clear that the technology teachers placed different emphasis on what was most important for the students to focus on in their projects product or process. This is very clear in the below statement:

\begin{abstract}
"In my teaching I do not have a big focus on the product and whether the students can make a nice product. I know some of the other teachers have that focus. I'd rather have the students illustrate that they have understood the process and they then stand with a poor product than I want them to spend all their time making a nice product and they therefore have no understanding of the process and thus end up making a bad report" (Field notes, 2018).
\end{abstract}

The teacher here clearly indicates that he, along with the rest of the teachers, has different perspectives on what students need to focus on and learn in this HTX discipline. Following these brief observations, the research goal is to assist in the creation of a coordinated language. To do so now demands that observations and dialog continue with an adjusted focus due to the awareness of the different materials teachers bring into use in the subject and how the methods and concepts from these materials are articulated in the classroom. With this renewed focus, the intent is not to create a uniformity in teachers' approach to the subject as one of the greatest strengths in the technology subject relates to the teachers' different skills that are brought into play in the students' project designs. The intent is rather to assist in developing a coordinated base for both teachers and students based on the teaching materials used in the subject - and with the teachers and the students' expertise in play - a broad base with a conceptualisation of all the main methods and concepts.

Another teacher mentions that he finds the process of writing projects as well as preparing products in the workshop equally important (Interviewee 7, 2019:11). He further adds that he is however concerned with the development of the technology subject:

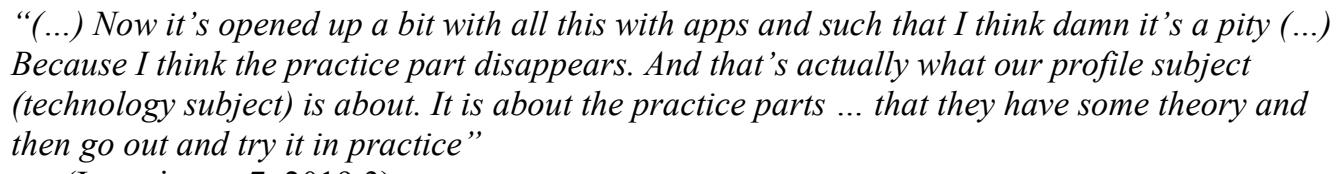
(Interviewee 7, 2019:3).

The teacher thus thinks that it is a shame that the students have been allowed to develop apps as a product for their project, as he believes that the practical part of working with products disappears. The teacher thus connects the work with products in the technology subject with something physical, where the students go to the workshop to create the product.

Another teacher also comments on when he thinks you can call a product a product. Is it something physical or is it okay to create an app as a product? As he says: "after all, it is for eternal discussion when a product is a product" (Interviewee 8, 2019:10). He then continues:

\author{
"(...) basically, I would say that there is the very engineer-like approach to it, and then there is \\ the more scientific approach to it (...) Now I am a biologist so it is clear enough where I stand \\ but I can well recognize the others and I can also well recognize the concerns of their appeal. I \\ also do not think there is much craft in a student making a 3D printing of something (...) But \\ there I would like you to think more scientifically and then say: what is that model for? What \\ can you use it for? (...) Not really for anything (anticipated student response) well which \\ model should you then have made instead?" \\ (Interviewee 8, 2019:10).
}

The teacher here also expresses that there are different approaches among technology teachers to what students should focus on when preparing projects. The quote expresses a great focus on the product, but that the teacher also sees that the colleagues do it very differently, which he attributes to the teachers' different educational backgrounds. 


\title{
4.2 Different educational background
}

The teachers having different backgrounds and that having to do with the fact that they see things differently will further be confirmed in the below quote:

"So of course, we are different and we are also a professional group where we are in that way very different in relation to some of the other subjects because yes, we have significantly more different backgrounds than many others" (Interviewee 1, 2019:10).

The teacher expresses here that it is very obvious that they as teachers are very different and that the professional group for the technology subject is in many ways also different from many of the other subjects and on the basis that they in the professional group for the technology subject have significantly more different backgrounds than in many other professional groups.

That the teachers have very different professional backgrounds is also confirmed in the next quote:

\begin{abstract}
"(...) It's a very interesting group of teachers because most of us have at least two years' work experience (...) from a private company or organization type other than a public educational institution (...) And that means that we have a lot of different experiences and draw on and it provides a good professional environment. But it also provides interesting conversations (...) That you are so different (...) and have been to different places have different approaches on how to approach the world (...) I experience it as a strength yes, I actually do, because we largely agree on what the Ministerial Order is about and what the goal is (...) I would say. But the road leading there is very different. And this is where we have to learn to accept that we have different ways of doing things, unless there are some colleagues who have problems making their teaching work and getting their students through (...)” (Interviewee 4, 2019: 1314).
\end{abstract}

Here the teachers focus on the fact that the group of technology teachers is an interesting group as they all have at least two years of work experience, as this is a requirement to become a technology teacher on HTX. This is from teachers' point of view seen as a positive thing as this means that the teachers have a lot of different experiences to draw from which he believes helps to create a good professional environment. Further the teachers see it as a strength that the teachers have such different backgrounds because they largely agree on the Ministerial Order. The way forward to everyone having the same understanding of what the Ministerial Order contains just varies from teacher to teacher and it is his position that it is important that the teachers learn to accept this fact. The teachers have different approaches and this should be okay unless there are some teachers who have a hard time making their teaching in the technology subject work and it therefore affects the students. Then action must be taken.

Another teacher agrees that the teachers are different and express that they have different profiles and personalities, but do not see this as a problem:

“(...) No, I think it may well be we each have our profile we each have our personality. We have slightly different educational backgrounds. We each have our work experience but I think we agree on the concepts. I actually think so (...)” (Interviewee 9, 2019:13-14).

It is further explained that despite differences in profiles, personality and educational background, she believes that the teachers agree on what the concepts they use in the technology subject contain. During the interview, I therefore ask whether the teacher also believes that it applies to the PBL concepts, e.g. how to define a problem:

\footnotetext{
“(...) I think so too. But it may well be that if you walk around and interview us now (...) then it may well be that you can find someone, but I actually believe it (...)” (Interviewee 9, 2019:1314).
}

The teacher agrees again. She expresses that she also believes that the teachers agree on what the PBL concepts used in the technology subject contain. At the same time, however, she is unsure whether the other teachers would agree with her statement if I walked around the school to interview them as well, but still sticks to her statement that she believes there is agreement on understanding the concepts. 


\title{
4.3 Problem-based learning
}

During an interview with a technology teacher from another HTX school, I ask the same question; What is a problem and is there agreement on this matter among the technology teacher group:

"Well, that's where we can still be in doubt about what is a problem and what is a problem
analysis and what has to be included in a project description so we can say that it is approved
(...) we can still get into discussions about that" (Interviewee 8, 2019:13).

It is expressed here that the teachers can still have doubts about what a problem really is, what a problem analysis is and what should be included in a project description. In the statement there is also expressed a difference in how the different teachers view the content of the different concepts and in cases where disagreements arise, teachers may well get into discussions about the content of the concepts. However, the same teacher also expresses a little later that there are actually some of the discussions surrounding the content of the PBL concepts and the concepts in the technology subject in general where discussion may not arise as can be seen in the first quote of the findings section. He expresses here that some of the discussions about the concepts are sometimes so difficult to take that they, perhaps based on the fact that the teaching group gradually knows each other so well, along the way have stopped taking the discussions. That there are many different ways of working with, among other things, PBL in the technology subject is also illustrated in the next quote. Here a technology teacher expresses the following:

\begin{abstract}
"(...) Last year we had seven different classes (...) And they have had seven different technology teachers (...) So when you ask the students to write a problem statement there are some who just writes one and others start to analyse for twenty hours and return with thirtyfive pages which of course have to do with the problem statement because otherwise it is not documented (Laughs)... it becomes so very very clear and in general the problem formulation that the students have learned in technology they know how to do that so there is no reason for me to get them to do it as I would do it. The students that have followed me can do that, but they are welcome to do it in other way. But then to get them to understand that there is something called a problem analysis which comes before (the problem statement) that can be a challenge (...) But no, it is (...) the experience from technology the students draw on in the technical science subjects and it is very versatile (...)" (Interviewee 1, 2019:11-12).
\end{abstract}

That there are many different ways of working with, among other things, PBL in the technology subject is also illustrated in the next quote. Here the teacher gives an example of what happens when she gives the students the task of writing a problem statement. When that is the case the students work very differently with the task because they come from different classes and have had different technology teachers. The teacher is aware of this and chooses not to force the students to do it the same way or do it the way she herself would have done it. But this presents some challenges as the students (third level students) have trouble accepting and being told that they have to work in a different way with PBL than they had to the last two years of their study. In the example the teachers tell the students that there is something called a problem analysis and it seems that the students have a hard time taking that in as it creates challenges and, in the example, lies the understanding that it may be because they have never been asked to prepare a problem analysis before, again because of the different ways of teaching the technology subject and teachers suggest that it also affects other subjects, as several of them are based on the knowledge they gain in the subject of technology.

Another teacher gives an example of the disagreement that unfolded about what PBL is, what the concepts in connection with PBL contain and how to work in the subject:
“(...) Well I have had a student who broke down (...) I had some vacation and then one of my colleagues took over. And I had said she (the student) wanted this problem statement and then he (the teacher) changed it to his interpretation of how it should be. He then tells her and then I come back from vacation and I say no (...) Well then, he was in one of the classes next door so I said I'll go get him so that we can just talk it through. And when we were standing there talking in front of her and all of a sudden, she broke down (...)” (Interviewee 7, 2019:22).

In this very concrete example, disagreements between two teachers have serious consequences for a student who breaks down on the basis of different expectations from the teachers. The teachers expect different things and it becomes too much for the student. However, the teacher elaborates and says that since that happened, the teachers have become better at communicating. 


\subsection{The conceptualising method in practice}

Through this dialog with the teachers about differences, different educational backgrounds and approaches to PBL and teaching materials, the idea arose of making a new basic text book for the technology subject. The idea arose one day I was in dialog with one of the technology teachers. He mentions that it could be nice that he uses educational material from several different basic books for the technology subject and on top of that he uses a lot of copies from other books he therefore thinks it could be nice with a new basic text book for the technology subject which gathers the materials. "(...) We are missing one book that brings it all together. I use many different books, but only a few things from each plus I have a large library on the computer with copies, assignments, etc. (...)" (Field notes, 15.03.2018). The plan to focus on the language and write it down in a new basic text book for the technology subject starts, what in the conceptualization method is also called subjectivization (Henriksen et al., 2004:25). We also have a dialog about what the teacher thinks such a basic text book should be able to do in addition to collecting all the materials used in one place. The teacher adds that he believes there is a need for: "(...) a book that is built on the process in the technology subject and which leads all the way to the exam project (...)" (Field notes, 15.03.2018). More specifically, it is also his opinion that a new textbook would have to contain more about environmental assessments, good manageable examples that students can relate to and it must not be too far-fetched as there are some students who are not good at reading (Field notes, 15.03.2018).

The next day I am back on HTX to observe the language in another class. However, I meet the teacher who came up with the idea for a new basic text book in the staffroom, where we again have a dialog about the idea of a new basic text book for the technology subject. Here we talk about, among other things, whether it should be a method book, i.e. one that gives students the "recipe" for how to make a technology project, whether it should be a printed book or an ebook and whether, for example, a reference work should be included (Field notes, 16.03.2018). Later the same day, I have a dialog with the teacher who teaches the technology class that I am observing on that day. In this way, I begin to quietly tell others about the idea with a new basic text book for the technology subject where the common concepts developed in the dialog are written down and this is where the externalisation begins (Henriksen et al., 2004:25). On March 21, 2018, I sent an e-mail to the chairwoman of the technology teachers' association, which is an association for all technology teachers on HTX schools throughout Denmark to present the idea with a new basic book:
“(...) The reason for this is that I hear from some of the teachers I have contact with that they miss a complete book for the subject Technology (I know there are some pieces and it should not be seen as a critique of the existing ones). The idea is to make a reference work with methods that are used in teaching combined with PBL. In this way, everyone will be able to have the same starting point in PBL, language / concepts, but at the same time it will be one very dynamic approach / model that all teachers / students can draw on for their teaching / project writing. I think that it will be able to substantiate this idea by creating a common language / conceptual apparatus (...)” (E-mail, 21.03.2018).

After three days, there will be a reply to an email from the chairwoman of the technology association and where she explains what she initially thinks about the idea of a new basic text book for the technology subject:
“(...) I think it sounds very exciting with a book, with the challenges it can present in terms of choice of form, content and target group. My personal point of view is that when teachers miss a book that represents the whole subject, it stems from the fact that they cannot identify themselves (and the subject) in the two books that already exist (...). The two existing books, in fact, cover the entire subject (Technology B), but of course based on the authors' perception of the correct choice of methods for the phases of the project processes. So, writing a book that covers everyone's desires are almost utopia (sorry, but that's how I see it). Conversely, a new (kind of) book can be quite justified (...)" (E-mail, 24.03.2018).

Subsequently, I plan a meeting with the chairman of the technology association to talk the possibilities of a new basic text book through. During the meeting, we talk about ideas for the structure of the book, content, possible partners and how we can start working on the book. Here it is suggested which publisher I could contact to make an agreement on publishing the book. The idea of noting the language we are constantly developing in a basic text book gradually changes here from being a subjective idea to becoming a shared idea between the technology teachers and myself and the idea is thereby legitimised (Henriksen et al., 2004:25). The book and the idea of a coordinated language for the 
technology subject are thus well on the way to becoming an objective given fact. I then contact a publisher who already publishes books for high school to hear if they might have an interest in publishing such a book. At the same time, work continues on the book idea through my dialog with the technology teachers while I am observing them in the classrooms. It is by a teacher suggested that the book should be interactive that the students themselves can adapt and move around in and save so that they have their own template or that they should at least be able to make notes in their own edition of the book. Furthermore, the teacher emphasizes that the book must provide some case examples that are completely down to earth. Nothing with calculations on wind turbines - students can not relate to it (Field notes, 06.04.2018). After a few days I get the first email from the publisher and they are interested in the book and in hearing more about the idea. Here, more specifically, we start by making plans and entering into agreements about the book but authorisations are not put on paper yet. It will not happen until 13.08.2018 where we get a confirmation from the publisher that they would like to publish the book: “(...) Systime would like to publish an upcoming textbook for Technology together with you based on Problem-based learning. We would therefore like to invite you to a meeting at the publisher, where we will start the process together (...)" (E-mail, 13.08.2018). The idea is therefore institutionalized and since the book is therefore also now a fact - the language must be written down in a book, the idea is also objectified (Henriksen et al., 2004:25). At this time, I have had many exciting dialogs with the technology teachers about the development of the idea of a new basic text book for the technology subject and through those dialogs we have created a language - one we can handle the idea with. Together we have transformed the abstracted idea of a new basic text book into concepts which frame some possibilities and constitutes a tool that can contribute to creating action. We are therefore also ready to materialise the idea, as efforts are now being made to put together the team of writers and editors to be used to materialise the idea. The original idea of a new textbook for the technology subject will thus be coupled with the resources that are available and which can help to materialize the idea. Thus, the people who actively participate in the process of developing the book create a routine around the work with the book a so-called; routinisation. In this way, it will now be possible to change the original idea into reality (Henriksen et al., 2004:25). "Through such a process the actors were able to create things, to change things" (Henriksen et al., 2004:26). We have also in the process together created a new language or in the case of the technology subject on HTX closer to a coordinated language or a merged language based on the existing fractions and in the process the teachers have also changed themselves in relation to the language which enables them to now handle the teaching of the technology subject based on the "new" language. Finally, it is about inaugurating the other technology teachers and other possible new colleagues in the project. After the book's publication, that process is well underway, for example on HTX in Aalborg, where the book the book is introduced to the other teachers by being discussed at subject group meetings and, among other things, included as a fixed teaching material in the teaching of the basic course; Product development (Henriksen et al., 2004:26). A work that continues to take place.

In creating this broad base for addressing both teachers and the students' aspects it is intentional that useful concepts will emerge, a coordinated language, which will enable the teachers to act. With coordinated conceptual devices teachers will obtain a toolbox enabling a focused discussion on the technology subject and its methodological features; a discussion that can help create a more solid disciplinary tradition on HTX through identification and creation of a coordinated language.

\section{Conclusion}

The article contributes on different levels. The conclusion is therefore divided into different sections; contributions on a local level, contributions on a national level and finally a general conclusion which are all are unfolded below.

The contribution to the concepts in the technology subject consists of a merged language or merged conceptual device which was created with the technology teachers on HTX. This has taken place continuously through the dialog we have had during the time I have spent on HTX and in the technology subject. The conceptual devices that have been merged include the concepts used in the teaching of the technology subject, including concepts of PBL and product development. The merged language is not created with an expectation that it will help to create a unification in the teaching of the technology subject. A unification in the technology subject is, firstly, impossible to expect as the teachers have so many different professional backgrounds; on the contrary, it should instead be seen as a great asset of the subject. More specifically, the merged language is created as an attempt to create an opportunity for teachers in the technology subject to discuss their practice and subject with each other and the students; therefore, the merged language was also written down and made into a basic text book for the subject technology. That way, the merged language became tangible for technology teachers and easier to start working with.

For the Danish Higher Technical Examination Programme and the technology subject, the development of a coordinated or merged language has had a significant impact on the teaching of the subject. At a local level, technology teachers are working on making the use of the merged language a routine through the developed textbook. This is done by the teachers gradually starting to use the book when teaching and referring to it when the students have to read about different topics. The new merged language is now also used for the basic course in product development which serves 
as an introduction to the Technology subject, as well as to some extent in the Technical science subject. At a more national level, it was planned by the subject consultant for the technology subject before the first corona shutdown that the new basic text book together with the existing books for the subject should be discussed against each other in order to get closer to a common direction in the technology subject.

Through the use of the conceptualising method and thereby the description of reality and the change process that is included, it has been possible to study the change in the language game that has taken place in the technology subject on HTX. A change that also took root in the organization and has helped to start up small changes in the form of: enabling discussions on the use of books and materials in the field of technology and changes thereto and a joint decision to use the new basic text book as a basis for the teaching of the new students. In conclusion, it can therefore be said that it has been possible to use PC in practice to unfold the language game used in the technology subject on HTX and through that create a change in the organisation.

\section{References}

Code, L. (2002). Feminist interpretations of Hans-Georg Gadamer. Penn State University Press.

Gadamer, H. G. (1962/1992). Truth and Method. Crossroads.

Henriksen, L.B., Christensen, J. B., Jørgensen, K.M., Nørreklit, L. \& O’Donnell, D. (2004). Dimensions of Change conceptualising reality in organisational research. Copenhagen Business School Press.

Henriksen, L. B. (2016a). Are they ready?: The Technical High School as a Preparation for Engineering Studies. In M. J. de Vries, L. Gumaelius \& I. B. Skogh (Eds.). Pre - university Engineering Education. Rotterdam. Sense Publishers. https://doi.org/10.1007/978-94-6300-621-7.

Henriksen, L. B. (2016b). Change, concepts and the conceptualising method. Proceedings of pragmatic constructivism, $6(2), 29-33$.

Henriksen, L. B. (2018). Language Games, Dialog and the Other. At the 17th European conference on research methodology for business and management studies. 12-13 July, 2018, Rome, Italy.

Jans, J. (2007). 'Et eksperiment i modvind' [An experiment in headwinds] In Kjærgård, P.M., Bendix, U., Johnsen, V. T. \& Andersen P. S. (Eds.). HTX 25 år med teknisk gymnasium—fra eksperiment til anerkendelse [HTX 25 years with the technical high school—from experiment to recognition]. Erhvervsskolernes Forlag: Odense, pp. $10-23$.

Jeppesen, M.M. (2020). “Agree to disagree”: technology teachers' perceptions and practices of problem-based learning $(P B L)$ in the Danish higher technical examination programme. In review at: Journal of problem-based learning in higher education.

Lyotard, J. (1979). The Postmodern Condition: A Report on knowledge. Manchester University Press: Manchester.

Nørreklit, L. (1973). Concepts: their nature and significance for metaphysics and epistemology. Odense University, studies in philosophy. (2).

Nørreklit, L. (1978). Problemorienteret forskningspraksis og den reale virkeligheds constitution. [Problem oriented research practice and the constitution of the real reality]. Aalborg University Press. Aalborg.

Nørreklit, L. (2004). Hvad er virkelighed? [What is reality?] In Vidensgrundlag for handling [Knowledge base for action] edited by J. Christensen.

Ministry of Education (2008) De gymnasiale uddannelser I Danmark: HTX https://www.uvm.dk/-/media/filer/uvm/udd/gym/pdf08/fakta/080201-faktaark-HTX.pdf (accessed 20 March, 2020).

Ministry of Education (2015) The Ministerial order: HTX: http://eng.uvm.dk/Education/Upper-Secondary-Education/Four-Upper-Secondary-Education-Programmemes-inDenmark/The-Higher-Technical-Examination-Programmeme-(htx) (accessed 20 March, 2020).

Ministry of Children and Education (2017). Curriculum, Technology subject A and B https://www.uvm.dk/gymnasiale-uddannelser/fag-og-laereplaner/laereplaner-2017/HTX-laereplaner-2017 (accessed 20 March, 2020).

Olsson, F. A. (2007). 'En pioner blev uundværlig' [A pioneer became indispensable]. In Kjærgård, P.M., Bendix, U., Johnsen, V. T. \& Andersen P. S. (Eds.). HTX 25 år med teknisk gymnasium-fra eksperiment til anerkendelse 
[HTX 25 years with the technical high school-from experiment to recognition]. Erhvervsskolernes Forlag: Odense, pp. 6-7.

Ulriksen, L., Holmegaard, H. T., Simonsen, B., Johnsen, V. T., Eriksen, U. (2008). Laringsmiljo og naturvidenskab på $\boldsymbol{h t x}$ - kvaliteter og udfordringer. [Learning environment and science on htx - qualities and challenges] 1. edition. Erhvervsskolernes Forlag. Odense.

Ulriksen, L. \& Holmegaard, H. T. (2008). Projektarbejde på htx - erfaringer og udfordringer i projektvejledning. [Project work on htx - experiences and challenges in project guidance]. MONA (2), 28-48.

Wittgenstein, L. (1953). The philosophical investigations. Macmillan. London. 